DOI: https://doi.org/10.32839/2304-5809/2020-3-79-81

UDC 37.091.12:378.811.111

Kudryavtseva Valentyna ${ }^{1}$

Kherson State Maritime Academy

\title{
INSTITUTIONAL FRAMEWORK OF UPGRADING MARITIME ENGLISH INSTRUCTORS SKILLS
}

Summary. The article is devoted to outlining the basic framework of upgrading Maritime English instructors' skills in compliance with the institutional needs. The author remarks that every training institution has its own philosophy of education which affects professional behavior of instructors as well as teaching methods and skills required from them. The educational model of upgrading knowledge and practical skills of Maritime English instructors, where the communicative approach is a priority, is outlined. The initial steps of implementing the communicative approach are presented with special attention to communicative lesson structures that differ for the support, operational and management levels of Maritime English. The abridged sample of Lesson Analysis Flow which serves as a checklist for planning and analyzing communicative lessons is provided. The author states that Maritime English instructors are consistently faced with challenges concerning Maritime English peculiarities and the onboard processes behind them as all of them are graduates of pedagogical or state universities who get no skills of teaching Maritime English. At the start of their work at a maritime training institution, they need to master communicative teaching skills and Maritime English. The types of teach-the teachers events are described in sequence, among them workshops, faculty development sessions, expert-classes, master-classes, CLIL meetings, lesson observation and analysis, and development of training modules for Maritime English course books.

Keywords: institutional needs, Maritime English instructors, communicative approach, upgrading teachers' knowledge and skills, ways of teaching-the-teacher.

Кудрявцева В.Ф. Херсонська державна морська академія

\section{ІНСТИТУЦІЙНА СТРУКТУРА РОЗВИТКУ УМІНЬ ВИКЛАДАЧІВ МОРСЬКОї АНГЛІЙСЬКОЇ МОВИ}

Анотація. У статті йдеться мова про розвиток умінь викладачів морської англійської мови у відповідності до потреб навчального закладу. Зазначається, що незважаючи на широку мережу різноманітних форм індивідуального підвищення кваліфікації викладачів з питань нових підходів до навчання студентів, можливість надання ними підтримки щодо трансформації нових знань у практичні уміння, особливо пов'язані зі специфічним змістом навчання морської англійської мови, обмежена. Автор зауважуе, що у кожного навчального закладу є своя фрілософія освіти, яка впливає на професійну поведінку викладачів, а також на методи навчання і уміння, що від них вимагаються. Окреслена навчальна модель підвищення знань і практичних умінь викладачів морської англійської мови, у якій пріоритетом $є$ комунікативний підхід. Описані початкові кроки впровадження комунікативного підходу, де особлива увага приділена різним структурам комунікативного заняття для рівня допоміжного обслуговування, операційного і управлінського рівнів використання морської англійської мови. Надано скорочений зразок схеми аналізу заняття у форматі списку запитань для планування і аналізу комунікативного заняття. Автор стверджуе, що у викладачів морської англійської мови постійно постають складнощі, пов'язані з особливостями морської англійської мови і знанням суднових операцій, тому що усі вони закінчили педагогічні або державні університети і не мають умінь навчати морської англійської мови. Починаючи працювати у морському навчальному закладі, їм необхідно оволодіти уміннями комунікативного навчання, морською англійською мовою і усвідомленням процесів, які відбуваються на суднах. Системна робота 3 навчання нових викладачів морської англійської мови, як і оновлення знань і розвиток методичної майстерності усіх інших викладачів у зв'язку з інноваціями у галузі судноводіння та інноваційними підходами у навчанні здобувачів вищої освіти визначаються необхідною умовою. Зазначається, що успішність становлення інституційної системи навчання викладачів морської англійської мови грунтуеться на спільних зусиллях керівництва закладу, компанії-роботодавця та ентузіазмі самих викладачів, робота яких спрямовуеться координатором, функції якого представлені, та координаційною радою з морської англійської мови. Послідовно описані типи заходів з навчання викладачів, серед яких науково-методичні семінари, методичні семінари-практикуми, експерт-класи, майстер-класи, заняття щодо навчання на основі інтеграції змісту і мови, аналіз відвіданих занять, розробка навчальних модулів для посібників з морської англійської мови. Ключові слова: потреби навчального закладу, викладачі морської англійської мови, комунікативний підхід, підвищення рівня знань і вмінь викладачів, способи навчання викладачів.

Problem statement. Upgrading teachers'

Pnowledgeandskillseitherbyindividuallydriven awareness or by institutional push has permanently been perceived to be of utmost importance. Throughout the world, there are thousands of in-service teacher training centres, online courses, agencies providing support for English language instructors, offering face- to-face and online courses to help them develop skills and learn new teaching approaches.

Undoubtedly, individual participation in development courses fosters innovation approaches to teaching. A thing they can not do, though, is the possibility to scaffold instructors' attempts to transfer new information into practical skills on-site and to tailor

${ }^{1}$ ORCID: https://orcid.org/0000-0003-4264-4229

(C) Kudryavtseva Valentyna, 2020 
the content to the institutional demands which are represented by research themes of its departments.

Paying tribute to those possibilities, it should be pointed out that every training institution has its own philosophy and, thus, strategy of education. This philosophy affects professional behavior of instructors as well as teaching methods and skills required from them.

Recent research and publications. Teachers and their way of thinking are most important in any educational system. Researches and, therefore, articles on institutional systems of upgrading teachers' skills are really scarce. It also refers to teachers of Maritime English or, in other words, Maritime English (ME) instructors.

As stated in the International Convention on Standards of Training, Certification and Watchkeeping for Seafarers (STCW), "Each party shall ensure that instructors, supervisors, and assessors are appropriately qualified for the particular types and levels of training or assessment of competence of seafarers either on board or ashore, as required under the Convention [7, p. 23].

Accordingly, a model training course of Maritime English, another document developed by International Maritime Organization, reads: “...training institutions and academies should note that this course more than fulfills the competences regarding English language contained in the STCW Code [6, p. 6]." And continues: "For the course to run smoothly and to be effective, considerable attention must be paid to the availability and use of qualified instructors of the English language" [6, p. 9].

Cole C., Pritchard B., Trenkner P., who dedicate most of their research to methodology of ME teaching and to in-service ME instructors training with certain attention to internal institutional processes, observed that "MET institutions, still often reluctant to recognize ME on an equal footing to Navigation or Marine Engineering, or to dedicate more instruction hours to already tight programmes, are nonetheless keen to find more effective instruction strategies" [2, p. 125]. They identified some of the "most important issues concerning the methodology of ME instruction, among them:

- the communicative approach to learning and teaching $\mathrm{ME}$

- the role of content-based learning

- competence-based learning as the basic IMO requirement

- the ME instructor as user, adapter, and developer of ME teaching resources (textbooks/course books and related materials [2, p. 139].

Another author dwelling on the standards of Maritime English training states that according to the STCW each MET institution must take responsibility for ME tutor competence as recommended by the IMO but as the IMO provides no tools to help align trainer competencies internationally, MET institutions need to collaborate with each other to align quality assurance worldwide [4, p. 55].

A group of researches echo the previous author's remarks voicing their opinion that "global standards governing communicative competence have been strengthened by IMO through its legal documents and different conventions. It is now recognized that globalization of maritime services has led to the adoption of Maritime English as a career tool ... Na- tional and international authorities, universities, training institutions need to develop effective strategies that meet these new demands" [1, p. 95].

We totally support the ideas expressed at International Maritime English Conference that "focusing on the linguistic and methodological requirements placed on the Maritime English instructor, s/he should undergo a process of "marinization": acquiring knowledge of and competence in the specific linguistic features of Maritime English as well as the specifics of the methodology of teaching Maritime English, and knowledge of the subject matter (maritime studies) acquired through 'twinning', i.e. in cooperation with the technical subject teachers and during occasional on-board training" [3, p. 160-161].

In a dissertation on the issues of upgrading ME instructors, the researcher affirms: "MET institutional management needs to motivate instructors to improve themselves not only because they have to, but also because they have to really feel committed and believe in it [5, p. 16]. Instructors and assessors, when they accept continued professional development, will be a major key of success to themselves and for their institutions. It is essential for MET instructors to maintain high levels of professional competence by continually upgrading their skills and knowledge... Implementation of MO standards on a global basis needs to be supported by a core of well-trained and trained professionals [5, p. 17].

In our research made at the initial stage of communicative approach implementation, we noted that "the communicative approach distinction is the similarity of its training process to that of real communication. To be able of developing learning tasks that would meet the students' needs and communicative approach specificity, teachers should realize how to use its methods for developing skills required for work at sea, in particular, correct pronunciation and usage of standard marine communication phrases, detailed understanding of what has been said, every day and professional communication on board" [9, p. 301].

The purpose of the research is to outline the basic framework of upgrading Maritime English instructors' skills in compliance with the institutional needs.

Presentation of the main material. Statements about requirements and obligations concerning ME instructors stumble over the real life circumstances of under-performance among teachers that is based either on their ignorance of the required knowledge and skills or on their inability to acquire them individually. It presents an enormous challenge for the training institution managers, be it the rector or department heads, and enormous annoyance and dissatisfaction for students and their parents/sponsors.

As a matter of fact, a tailored teaching of teachers (TOT) program would support such teachers' efforts to become intentional ME instructors striving to improve personal teaching skills to meet the institutional requirements. In some cases, teachers should be forced to do some of the work by themselves.

A unique system of teaching ME instructors has been implemented and is getting its further development at our maritime training institution.

It all started with a shipping industry company initiative to launch a project on implementation of communicative approach to teaching Maritime English at the academy to comply with the guidelines of IMO Model Course "Maritime English" which asserts that 
"The instructor should be a qualified teacher of English language who has been trained in the Communicative Approach, content-based instruction and task-based learning etc. to English language teaching and has a broad understanding of maritime subjects" [6, p. 37].

The initial success in implementing the communicative approach was due to the joint efforts of the industry company, the academy management and enthusiasm of ME instructors streamed by an appointed communicative teaching coordinator (a teacher with a sufficient communicative teaching experience behind) and establishment of the coordination council on ME issues as the training institution comprises three English language departments and three methodological committees of English language teachers at its maritime college.

According to Rector's order, the coordinator's responsibilities include, but are not limited to, planning the coordination council activities, monitoring the process of communicative and competency-based training, approves of and analyses the content of workshops and other TKT, personally conducts certain TKT events, develops some methodological guidelines on the issues of importance, consults ME instructors on specific aspects of planning and organizing communicative lessons.

The first project stage concerned defining the goal and methods of the in-service teacher training within the institution. As our experience proves, conducting a series of workshops on specific aspects of communicative approach at the project start and further on is truly effective: ME teachers gain understanding of the communicative teaching principles, lesson stages, types of appropriate exercises and activities etc. Unexpectedly, designing a communicative lesson topic and objective posed special challenges to ME instructors. All of them were inclined to stick to traditional practice of module-wide lesson topic (e.g. Types of Cargoes) and several lesson objectives, only one of them having some non-distinctive reference to teaching Maritime English. With about seventy teachers of English, it took considerable amount of time and efforts to adapt Bloom's taxonomy to our needs and to help ME instructors with developing purposeful objectives of communicative lessons.

The workshops need to be followed by teachers' conversion of their theoretical knowledge into practical teaching skills. Such skills can appear in twinning the teachers' thorough preparation and the coordinator's lesson attendance and analysis, especially done together with other project participants. A possible option here is conducting demonstration lessons by the ME instructors whose methods of communicative teaching have become adequate to those recommended in Instructors Manual of the Model Course [6, pp. 200-333]

Once most teachers got familiarized with a variety of communicative exercises and activities to use, they were provided with a Lesson Analysis Flow which served as a checklist for planning their lessons and analyzing the lessons attended by them:

1. Lesson topic and objective: Are the topic and objective formulated correctly? Do the topic and production correspond to the lesson objective? How is the objective presented? Does the lesson topic correspond to the syllabus?

2. Starter: Are all SS engaged in speaking? Does the starter assist SS in turning their brains to English? Is the classroom atmosphere positive?
3. Presentation stage: What language items are presented? What techniques are used? Is the meaning clear for students? How is the language output organized?

4. Practice stage: How long does it last? Is the practice stage subdivided into controlled exercises and semi-controlled activities? Do the lesson exercises and activities correspond to the objective? Does the teacher correct students' mistakes? How? Does the teacher monitor students' ability to use the target language correctly? Are the instructions clear and brief?

5. Interaction: Is the lesson focused on communication? What forms of interaction are used? Is the lesson student-centered? Is there enough talking time for students?

6. Production stage: Is the objective achieved at the production stage? Is the new topical vocabulary items / grammar structure used in the production context? How many students are involved? Does the production activity correspond to the mariners' needs?

The improving ME instructors' skills of teaching communicatively and the improving students' skills in using Maritime English as well as our understanding of great differences in students' knowledge, life and onboard experience at junior and senior years of study triggered the necessity of varied lessons structure. We devised detailed structures of PPP (Presentation, Practice, Production) format for the support level (first and second years of study) where the students are taught General Maritime English; EASA (Engage, Activate 1, Study, Activate 2) format for the operational level (third and fourth years of study) where the students are taught Specialized Maritime English, and Patchwork format (a variation of EASA format with a possible option E-A-S-A-E-S-A) for the management level (fifth and sixth years of study) where students are taught English for Maritime Business.

At 3P-structured lessons, which is practically $4 \mathrm{P}$ with Preparation added, teachers present new language items (vocabulary, grammar, and phonology) in limited context to be learnt by students through demonstration, explanation, and drilling. Having realized the students understand the new context, the teacher organizes their practice of it by doing controlled exercises and semi-controlled / freer activities. At the final stage of the lesson, students are free in using the language the need to do an activity or task set by the teacher. The PPP lesson structure is necessary and effective for beginners in learning Maritime English as well as for low output students. It should ne noted that PPP lessons need some teacher-centered periods as is the case with the presentation stage and, to some extent, with controlled exercises at the practice stage and with feedback at the lesson closure.

The EASA lesson structure, on the contrary, can be completely student-centered if the teacher is knowledgeable, methodologically artful, creative, enthusiastic and able to establish the healthy classroom climate allowing students to share their life and onboard experience, ideas and suggestions, trust the group mates and the teacher, and feel encouraged, motivated, and confident. Undoubtedly, departments develop Maritime English syllabi, ME instructors design lesson plans, but those are the students who perform each task in the way they perceive it, initiate their ideas and opinions, debate and role play, point out what language items, structures are not clear for them, and figure out meanings and solutions. 
The Patchwork lesson structure is, surprisingly as it may seem, a no-structure lesson. It is based on a topic-objective- final output logistics in which the stages - Engage, Study and Activate - may follow in any sequence and be of any reasonable length. Here, the MET instructors' excellence should be at its highest. Especially, due to the students' status - they have worked as deck officers on vessels to get experience and be promoted to the captain's position - and due to the management level of the Maritime English course which is designed for students who seek roles as leaders in the world shipping industry. The future masters should be taught by experienced ME instructors to be able to integrate practice and theory for the graduates to gain necessary management skills in oral communication, problem-solving, critical thinking, risk assessment, preparing the vessel for inspection.

As it prompts, another wave of teacher training workshops on communicative lessons structures followed, with task-based teaching and learning methodology chosen for working with senior students (third - sixth years of study).

Faculty development sessions (FDS), done by the coordinator, serve as a tool for improving teachers' skills to conduct communicative lessons. They are normally in the form of feedback to the teachers whose lessons were attended, mostly as round-table discussions with a slight input from the facilitator. FDS done by ME instructors are mostly on some technical aspects of teaching, like ways of using internet learning platforms, test validity etc.

Alongside with the methodological issues, we came to a consensus on the necessity of conducting expert classes for ME instructors. It's common practice in Ukraine that, on one hand, navigation officers prefer to deliver lectures and seminars in specialized disciplines in Ukrainian instead of English language; on the other hand, pedagogical university graduates get no skills of Maritime English teaching. Therefore, they are consistently faced with challenges concerning Maritime English peculiarities and the onboard processes behind them.

For ME instructors, interdisciplinary cooperation is of great value, and, moreover, a priority. This collaboration includes attending lectures delivered by faculty members of specialized departments, getting consultations from them on the issues connected with the forthcoming module to teach or with the content of the training module to be developed for a student's book. Expert classes, or short practical presentations on a specific onboard operation, or equipment items, or any other issues of difficulty done by former or acting captains and first officers enjoy popularity among ME instructors. The expert classes are about the basic aspects of navigation, such as bridge equipment, mooring, traffic separation scheme, bridge procedures, COLREG, communication at Sea, life-saving appliances etc.

CLIL (Content and Language Integrated Learning) sessions are another instrument for teachers to understand ways of merging the maritime issues with the communicative teaching methodology. These are mostly prepared and conducted by developers of course book modules. The purpose of CLIL sessions is: to familiarize MET instructors with the professional content of a module, its peculiarities, special options for high and low output students, methods and techniques chosen for doing controlled exercis- es, semi-controlled activities and productive tasks as well as the IMO documents to be learnt by students with a permanent attention to standard marine communication phrases. Team-teaching when a MET instructor and a navigation expert design a CLIL session on a training module of the third-fourth years of study are preferable because the contextual, methodological, and professional aspects of the same topic to teach and the competency to require from students are interpreted by the facilitators from different perspectives. It helps teachers see a situation from two points of view and understand it better.

Traditionally, training institutions of higher education in Ukraine have policies on teacher - teacher lesson observations aimed at learning from each other and sharing personal opinion on what should be improved. It's clearly understood that teachers' feedback may be brief and not truly sustainable for psychological and time constraints reasons. In our case, the coordinator's responsibility lies in developing a communicative lesson observation format supplemented with a lesson analysis sheet, teach all ME instructors, including heads of English language departments, some specific ways of lesson observation and analysis, and personally attend, observe, and help optimize teaching and learning processes with detailed performance feedback. Positive feedback enhances the teacher's motivation to become more reflective as well as more conscious of the practical steps to achieve the lesson objective.

A year ago it was decided to study effects of sequential teaching in the same group of fourth-year students for two months. Sequential teaching is a co-teaching model when two teachers conduct lessons in turn, with one teacher planning and conducting a lesson, another teacher observing it, assisting if necessary, giving feedback later on. Every day the teachers' roles were swapped. To do it, they needed to agree on the topics of a set of lessons, to design the lesson plans in advance, to gain mutual trust, and stay enthusiastic to get positive experience. Eventually, the process was perceived as an incredible opportunity to share ideas, techniques, handouts, visual aids, and time. Some tangible outcomes to mention are: increased motivation of students $(87 \%$ of them appreciated such approach), mutual observation benefits, deeper understanding of the colleague's methodological techniques and tricks, more detailed and thorough elaboration of lesson plans, and profound feedback.

Most educationalists would agree that the teacher's art 'lies in getting the right mix of ingredients at the right time and in the right context', with the interaction between structure and freedom [8, p. 102]. Thus, the teachers who managed to cope with the communicative teaching requirements established for the institutional needs were given freedom in selecting and using any methods, techniques and lesson structure with the aim of developing students' communicative skills.

Seemingly beyond the subject matter, development of training modules for Maritime English course books is a great opportunity for teaching the teachers, in which self-teaching is of basic importance. While implementing the communicative approach to teaching Maritime English, we realized the need for course books to accompany the Maritime English syllabi. Consequently, the process of developing course books was launched. The process looks like this. An ME in- 
structor gets a training module to develop following the approved criteria. The working group meets to discuss the module title, its topics and communicative skills to be mastered by students providing the developer with the training materials they have. The developer creates the topic after topic emailing it to the working group members for feedback. The final product is again discussed at the working group meeting.

To develop a module, a teacher has to find and study proper IMO documents, select standard marine communication phrases, search for appropriate materials in internet, consult with former and acting deck officers, choose visual aids, decide on the exercises, activities and tasks to take students up to the communicative skills, negotiate a lot of issues with the working group members, then, after the approbation period, get feedback on ways to improve the content and methodology used, and later conduct a CLIL meeting. This process can be successful in case the module developer applies ideas from the workshops, faculty development sessions, expert-classes, lessons observed and the like.

Conclusions. At present, all teaching-of-teachers (TOT) events are subdivided into direct and indirect types:

1) Direct TOT - theoretical workshops to enhance teachers' acquisition of new scientific and methodological ideas, practical faculty development sessions (FDS) of two types - as detailed instruction for new- comers and as feedback to the teacher whose lesson has been observed, master-classes, expert classes, and CLIL meetings. Conducted mostly by teachers themselves under the coordinator's guidance and supervision, they serve the major purpose - initially, teachers-facilitators need to thoroughly understand what they are going to teach others, then design a plan to try and convey it in a simple and motivating manner, and finally, implement and demonstrate it;

2) Indirect TOT - a) teacher-teacher lesson observation, with sequential teaching being the extreme option of it; b) individual development of training modules for Maritime English course books monitored and supervised by members of the appropriate working group.

Our practical steps in upgrading ME instructors' skills of communicative teaching and their outcomes have provided evidence that this type of institutional training network creates professional development opportunities for each ME instructor in meeting the demands of the institution and the industry partner.

As future plans within this training network, we envisage deeper work on the content taught, including development of a new generation of course books for the Maritime English syllabi, as well as organize discussions and workshops to implement contemporary approaches to the teaching and learning processes, among them personalized instruction and active learning.

\section{References:}

1. Celo, E., Danaj, L., \& Celo, J. Maritime English - Teaching Competencies in Facilitating Difficulties with Students. European Journal of Multidisciplinary Studies. Jan-Apr 2016. Vol. 1. Nr. 2. P. 95-103.

2. Cole, C., Pritchard, B., \& Trenkner, P. Maritime English instruction - ensuring instructors competence. URL: https://www.researchgate.net/publication/28210716_Maritime_English_instruction_ensuring_instructors_ competence (assessed: 20.10.2019).

3. Cole, C., Pritchard, B., \& Trenkner, P. The Profile of an Integrated Maritime English Lecturer - Status-Quo and NiceTo-Have. Proceedings of IMEC-25 (Istanbul, 23-26 September, 2013). Istanbul: Piri Reis University. P. 152-165.

4. Gabrielli, A. Standardasing Maritime English Training and Assessment through International Coordination of Content-Based Instruction. Scripta Manent. 2015. 10(2). P. 52-62.

5. Gamil, T. Upgrading MET Instructors: the skills and Knowledge Enhancement Demanded by MET Stakeholders. URL: https://commons.wmu.se/cgi/viewcontent.cgi?article=1405\&context=all_dissertations (assessed: 20.11.2019).

6. Model Course 3.17. Maritime English. URL: https://ru.scribd.com/document/261953765 (last assessed: 15.11.2019).

7. STCW Convention and STCW Code. 2017 Edition. URL: https://navlib.net/wp-content/uploads/2018/06/STCW2017.pdf (assessed: 23.09.2019).

8. Woods, P. Critical Events in Teaching and Learning. Routeledge, New York, 2012. Available from: https://books. google.com.ua/books/about/Critical_Events_in_Teaching_and_Learning.html?id=A9ad42J6feoC\&redir_esc=y

9. Kudryavceva, V.F. Marlou Navigejshn - morskoj institut: organizaciya obucheniya anglijskomu yazyku. Nauka ta osvita v suchasnomu universiteti v konteksti mizhnarodnogo spivrobitnictva: materiali Mizhnarodnoyi naukovopraktichnoyi konferenciyi (Mariupol, 23-25 travnya 2011 r.). Mariupol: MDU, 2011. S. 290-292.

\section{Список літератури:}

1. Celo E., Danaj L., Celo J. Maritime English - Teaching Competencies in Facilitating Difficulties with Students. European Journal of Multidisciplinary Studies. Jan-Apr 2016. Vol. 1. Nr. 2. P. 95-103.

2. Cole C., Pritchard B., Trenkner P. Maritime English instruction - ensuring instructors competence. URL: https://www.researchgate.net/publication/28210716_Maritime_English_instruction_ensuring_instructors_ competence (assessed: 20.10.2019).

3. Cole C., Pritchard B., Trenkner P. The Profile of an Integrated Maritime English Lecturer - Status-Quo and NiceTo-Have. Proceedings of IMEC-25 (Istanbul, 23-26 September, 2013). Istanbul : Piri Reis University. P. $152-165$.

4. Gabrielli A. Standardasing Maritime English Training and Assessment through International Coordination of Content-Based Instruction. Scripta Manent. 2015. 10(2). P. 52-62.

5. Gamil T. Upgrading MET Instructors: the skills and Knowledge Enhancement Demanded by MET Stakeholders. URL: https://commons.wmu.se/cgi/viewcontent.cgi?article=1405\&context=all_dissertations (assessed: 20.11.2019).

6. Model Course 3.17. Maritime English. URL: https://ru.scribd.com/document/261953765 (assessed: 15.11.2019).

7. STCW Convention and STCW Code. 2017 Edition. URL: https://navlib.net/wp-content/uploads/2018/06/STCW2017.pdf (assessed: 23.09.2019).

8. Woods P. Critical Events in Teaching and Learning. Routeledge, New York, 2012. Available from: https://books. google.com.ua/books/about/Critical_Events_in_Teaching_and_Learning.html?id=A9ad42J6feoC\&redir_esc=y

9. Кудрявцева В.Ф. Марлоу Навигейшн - морской институт: организация обучения английскому языку. Наука та освіта в сучасному університеті в контексті міжнародного співробітництва : матеріали Міжнародної науково-практичної конференції (Маріуполь, 23-25 травня 2011 р.). Маріуполь : МДУ, 2011. С. 290-292. 